\title{
The Integration and Reliance on Technology to \\ Enhance the Independence and Accountability \\ of Company Directors in South Africa
}

\section{F Hamadziripi ${ }^{\star}$ and H Chitimira**}

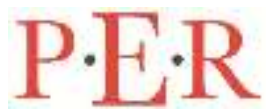

Pioneer in peer-reviewed, open access online law publications

\section{Authors}

Friedrich Hamadziripi

Howard Chitimira

\section{Affiliation}

North-West University,

South Africa

\section{Emails}

fhamztel@gmail.com

Howard.Chitimira@nwu.ac.za

Date Submission

28 October 2020

Date Revised

8 June 2021

Date Accepted

8 June 2021

Date published

29 June 2021

\section{Editor Dr TV Warikandwa}

How to cite this article

Hamdziripi $\mathrm{F}$ and Chitimira $\mathrm{H}$ "The Integration and Reliance on Technology to Enhance the Independence and Accountability of Company Directors in South Africa" PER / PELJ 2021(24) - DOI http://dx.doi.org/10.17159/1727$3781 / 2021 / v 24 i 0 a 10737$

\section{Copyright}

\section{DOI}

http://dx.doi.org/10.17159/17273781/2021/v24i0a10737

\begin{abstract}
The most indispensable means of change in contemporary business society is technology because it offers convenience to both businesses and their clients. Almost every business has been influenced by technology. Traditional corporate governance systems have been affected as technology has ceased to be a mere business enabler but is now a source of a company's future potential opportunities. The infusion of corporate governance and technology has been quite slow in South Africa. This may either be attributed to the fact that it is costly to do so, at least in the short term, or that company directors in South Africa do not yet trust technological measures with corporate decision-making input. Consequently, the impact of decision support technology on corporate entities and their governance has received less academic interest in South Africa than in developed countries. This article seeks to discuss the integration and reliance on technology to enhance corporate governance principles in developing countries like South Africa. The article also discusses the practical challenges and the benefits to be anticipated by directors in South Africa when they integrate technology in decision making to enhance their independence and accountability.
\end{abstract}

\section{Keywords}

Big data; artificial intelligence; independence; accountability; decision making; company directors. 


\section{Introduction}

The most influential means of change in contemporary business society is technology because it is convenient to businesses and their clients. ${ }^{1}$ The scarcity of literature on the integration of corporate governance and technology in South Africa makes it pertinent to define some key terms that are employed in this article. Technology comprises of the infrastructure, devices, systems and software that produce, transfer or process information to facilitate business decisions. ${ }^{2}$ There is no universally accepted definition for artificial intelligence (Al). ${ }^{3}$ However, John McCarthy, who coined the term Al, defined it as the art and engineering of making intelligent machines, particularly intelligent computer systems. ${ }^{4}$ This definition, though archaic, remains relevant even today because it retains the key characteristics of $\mathrm{Al} .{ }^{5} \mathrm{Al}$ can also refer to a computer programme that performs tasks that normally require human intelligence such as visual perception, speech recognition, decision making and language translations. ${ }^{6}$

Almost every business has been influenced by technology. ${ }^{7}$ Traditional corporate governance systems have been affected as technology has ceased to be a mere business enabler but is now a source of a company's future opportunities. ${ }^{8} \mathrm{Al}$ is a form of digital technology that has long been incorporated in the medical and business fraternities in other countries as

Friedrich Hamadziripi. LLB (cum laude), LLM, LLD (UFH). Post-Doctoral Research Fellow, North West University, South Africa. Email: fhamztel@gmail.com. Orcid: https://orcid.org/0000-0002-7034-1279. This article was initially presented at the $2^{\text {nd }}$ Annual Colloquium on Corporate and Financial Markets Law at North-West University, Faculty of Law on 29-30 October 2020. In this regard, the author wishes to acknowledge the expert input of Prof $\mathrm{H}$ Chitimira.

** Howard Chitimira. LLB (cum laude), LLM (UFH), LLD (NMMU). Research Professor and Professor of Securities and Financial Markets Law, Faculty of Law, North West University, South Africa. Email: Howard.Chitimira@nwu.ac.za. Orcid: https://orcid.org/0000-0003-1881-1242.

Bravard 2015 https://hbr.org/2015/09/all-boards-need-a-technology-expert.

Part 1 of the King IV Code on Corporate Governance 2016 (IoDSA King IV Code).

Liu and Lin 2020 Harv Int'I LJ 413.

Petrin 2020 Colum Bus L Rev 965-1030, while referring to McCarthy Date unknown http://jmc.stanford.edu/artificial-intelligence/what-is-ai/index.html. See also Liu and Lin 2020 Harv Int'l LJ 407. See Petrin 2020 Colum Bus L Rev 965-1030; Liu and Lin 2020 Harv Int'l LJ 407; Hilb 2020 JMG 1.

Kamalnath 2020 Alb L Rev 44.

Bravard 2015 https://hbr.org/2015/09/all-boards-need-a-technology-expert.

Foreword to the IoDSA King IV Code. 
an aid to decision making. ${ }^{9}$ The infusion of corporate governance and $\mathrm{Al}$ has been quite slow in South Africa. ${ }^{10}$ This could be due to fact that the integration of $\mathrm{Al}$ is expensive and most company directors in South Africa do not trust machines with decision-making input. Although about $40 \%$ of companies in South Africa use some form of Al in general, the integration and reliance on $\mathrm{Al}$ technology as a decision support tool by company directors remains very low. ${ }^{11}$ For example, a 2018 survey conducted by SYSPRO Private Limited in 400 South African companies revealed that only $13 \%$ of information technology (IT) companies' decision makers used big data and machine learning for decision making. ${ }^{12}$ Consequently, the impact of decision support technology on corporate entities and their governance has received less academic interest in South Africa when compared to that in other countries. ${ }^{13}$

This article seeks to discuss the integration and reliance on technology to enhance corporate governance principles in developing countries like South Africa. South Africa has introduced and refined a code of corporate governance in the form of King Reports I, II, III and IV. ${ }^{14}$ Given its corporate governance advances, South Africa can serve as a leader in the

Petrin 2020 Colum Bus $L$ Rev 967-968 records that in 2018 the chief executive officer (CEO) of SalesForce revealed that he was using an algorithm to comment on deliberations during the company's weekly staff meetings. In 2014 Deep Venture Capital, which is a company based in Hong Kong, was using an Al machine called VITAL to corroborate the board's decision making. Financial companies in the United States of America (USA) have also been using similar technologies to survey the markets and generate suggestions for directors. Also see Hamilton et al $2019 \mathrm{~J}$ Oncol Pract 277. Both developing and developed countries use the same software products. For example, apple products are sold in the USA and South Africa and most insurance companies in South Africa have bought software from the USA to deal with big data. SYSPRO 2018 https://www.researchandmarkets.com/reports/4715503/mobilecorporation-in-south-africa-2018.

11 Microsoft News Center 2020 https://news.microsoft.com/en-xm/2020/02/19/theseare-the-skills-south-africa-needs-to-compete-in-the-4th-industrial-revolution/.

However, it must be noted that the statistics relied on did not differentiate between listed and unlisted companies. Insurance companies who are not listed on the Johannesburg Stock Exchange (JSE) make use of artificial intelligence (AI) to some extent.

12 SYSPRO $2018 \mathrm{https} / / /$ www.researchandmarkets.com/reports/4715503/mobilecorporation-in-south-africa-2018. The above statistics apply to South Africa in general. The picture would be different if consideration were to be given to the activities of a company. For example, an insurance company with more than 200 000 policy holders would more likely make use of $\mathrm{Al}$.

13 Hilb 2020 JMG 2; Alalawneh and Alkhatib 2020 EJISDC 1-3; Dignam 2020 Cambridge $J$ Reg Econ Soc 38-40. There is no difference between first- and thirdworld countries in this regard since all countries use similar software except from an economic perspective. Muniandy and Hillier 2015 Pacific-Basin Finance Journal 109. 
integration of technology and directorial independence and accountability. ${ }^{15}$ Some African nations such as Zimbabwe, ${ }^{16}$ Ghana $^{17}$ and Kenya ${ }^{18}$ have already partially modelled their company law and corporate

15 Muniandy and Hillier 2015 Pacific-Basin Finance Journal 109.

16 For example, see ss 100(1) and (2) of the Companies and Other Business Entities Act 4 of 2019 [Chapter 24:31] provides that "The board of directors may issue authorised shares only for adequate consideration to the company, as determined by the board of directors; or in terms of conversion rights associated with previously issued shares or debentures of the company; or as a capitalisation share. Before a company issues any particular shares, the board must determine the consideration for which, and the terms on which, those shares will be issued" and ss 40(1) and (2) of the South African Companies Act 71 of 2008 (Companies Act 2008) provides that "The board of a company may issue authorised shares only for adequate consideration to the company, as determined by the board; in terms of conversion rights associated with previously issued securities of the company; or as a capitalisation share as contemplated in section 47 . Before a company issues any particular shares, the board must determine the consideration for which, and the terms on which, those shares will be issued". Also see s 102(1) of the Companies and Other Business Entities Act 4 of 2019 [Chapter 24:31] which provides that "for any purpose of this Act, a company satisfies the solvency and liquidity test at a particular time if, considering all reasonably foreseeable financial circumstances of the company at that time the assets of the company or, if the company is a member of a group of companies, the aggregate assets of the company, as fairly valued, equal or exceed the liabilities of the company or, if the company is a member of a group of companies, the aggregate liabilities of the company, as fairly valued; and it appears that the company will be able to pay its debts as they become due in the ordinary course of business for a period of twelve (12) months after the date on which the test is applied; or in the case of a distribution contemplated in paragraph (a) of the definition of 'distribution' in section 2, twelve (12) months following that distribution" and s 4(1) of the Companies Act 2008 which provides that "for any purpose of this Act, a company satisfies the solvency and liquidity test at a particular time if, considering all reasonably foreseeable financial circumstances of the company at that time the assets of the company, as fairly valued, equal or exceed the liabilities of the company, as fairly valued; and it appears that the company will be able to pay its debts as they become due in the ordinary course of business for a period of 12 months after the date on which the test is considered; or in the case of a distribution contemplated in paragraph (a) of the definition of 'distribution' in section 1, 12 months following that distribution".

17 For instance, compare s 35(2) read together with item 6 of Schedule 5 of the Companies Act 2008 and s 43 of the Ghana Companies Act 992 of 2019 provide that "a share does not have a nominal or par value" and "the shares created or issued under this Act are shares of no par value" respectively. Regarding the legal nature of shares, compare section 42(1) and (2) of Ghana's Companies Act 992 of 2019 , which provide that "the shares of a member in a company are movable property. The number of shares in a company and the rights and liabilities attaching to the shares are dependent on the terms of issue" and s 35(1) of the Companies Act 2008 which states that "a share issued by a company is movable property, transferable in any manner provided for or recognised by this Act or other legislation". Ghana's 2010 Code of Best Practices for Corporate Governance relating to independent non-executive directors is similar to principle 2.16 of South Africa's King III Code on Corporate Governance 2009 (IoDSA King III Code).

18 The Capital Markets Authority of Kenya published the Code of Corporate Governance Practices for Issuers of Securities to the Public, 2015 which adopted 
governance codes on the South African Companies Act 2008 and the King Reports on Corporate Governance. ${ }^{19}$ The article also discusses practical challenges and the benefits to be anticipated by directors in South Africa as they become more reliant on technology to enhance their independence and accountability.

The article also discusses the consideration of technology as a tool for enhancing corporate governance in South Africa. Thereafter, an analysis of the integration of $\mathrm{Al}$ into corporate governance as a way of optimising the independence of company directors will be provided. Furthermore, the integration of Al into directors' decision making will be examined in the context of the directors' duty of care, skill and diligence relevant to the processing of data. The question of whether the inclusion of a technology expert on every board should be mandatory in South Africa is explored. Lastly, concluding remarks are proffered.

\section{Problem statement}

Regardless of the influence of technology on most businesses, there has been a dearth of literature on the use of and reliance on innovative technology to promote good corporate governance standards by company directors in South Africa. As a result, the potential benefits of integrating technology such as big data, Al and cognitive computing systems to enhance directorial independence and accountability have not yet been considered in South Africa. Furthermore, the question whether companies in South Africa should have a technology expert has not been sufficiently addressed. This article addresses these two issues and seeks to trigger further research on the integration of technology to promote good corporate governance measures in South Africa.

\section{Technology as a tool for enhancing good corporate governance practices in South Africa}

Al could be utilised to efficiently analyse voluminous corporate data and produce results at a rate human beings cannot match. ${ }^{20}$ There are three different levels at which South African company directors can integrate $\mathrm{Al}$ technology to enhance their independence and accountability. The first

the apply or explain approach, the same regime as under South Africa's King III Code of 2009. Additionally, Kenya's Code contains corporate governance provisions relating to board independence and board diversity that are similar to those contained in South Africa's King IV Code of 2016.

19 Muniandy and Hillier 2015 Pacific-Basin Finance Journal 109.

20 Dignam 2020 Cambridge J Reg Econ Soc 38. 
one is known as assisted Al, which entails the execution of certain tasks by $\mathrm{Al}$ without the machine becoming an independent decision-maker. ${ }^{21}$ Assisted Al can completely assume all administrative duties such as setting a record date for determining shareholder rights, ${ }^{22}$ calling a shareholders' meeting ${ }^{23}$ and delivering notice of meetings. ${ }^{24}$ Considering that company secretaries generally spend most of their time on administrative work such as ensuring that the minutes of all shareholders meetings, board meetings and the meetings of any committees of the directors are properly recorded, the integration of and reliance on assisted Al by South African company directors would save them a lot of time. ${ }^{25}$ Company directors may also use Al to prepare for board meetings and to provide sound opinions ${ }^{26}$ Currently, applications such as Google assistant can compose emails based on voice prompts and set up and keep track of schedules of meetings. In the business context, assisted Al can be used by company secretaries to take and compile notes during board meetings, to schedule meetings and to prepare reports for directors. ${ }^{27}$

The second level at which South African company directors can incorporate Al to enhance their independence and accountability is known as augmented or advisory Al. This involves the use of algorithms to aid human intelligence without the algorithm's assuming the role of an independent director. ${ }^{28}$ Augmented Al can assist company directors in South Africa with judgmental decisions which require creative thinking without absolving directors of their responsibility and liability. ${ }^{29}$ South African company directors can employ augmented $\mathrm{Al}$ as a valuable tool in their decision-making process. Augmented Al may ask and/or answer questions and develop simulations of complex models of various business scenarios. ${ }^{30}$ Augmented Al could increase the productivity and quality

Petrin 2020 Colum Bus L Rev 981; Hilb 2020 JMG 11.

See s 59(1) of the Companies Act 2008. S 1 of the Companies Act 2008 defines a record date as the date on which a company determines the identity of its shareholders and their shareholdings. See s 61(1) of the Companies Act 2008. Section 62(1) read together with $s 6$ of the Companies Act 2008. S 88(2) provides that most administrative duties of a company are done by the company secretary. Section 88(2) of the Companies Act 2008; Petrin 2020 Colum Bus L Rev 984. Principle 1 of part 5.1 of loDSA King IV Code and ss 76(4)(a)(i) and (b) of the Companies Act 2008.

Petrin 2020 Colum Bus L Rev 981; Hilb 2020 JMG 11. However, s 86(1) of the Companies Act 2008 provides that not all companies in South Africa are required to have company secretaries. 
decision making of South Africa's company directors. ${ }^{31}$ Augmented Al does not seek to replace human beings but it aids human intelligence by providing information that would either be unavailable or very difficult or time-consuming to find for company directors. ${ }^{32}$ Augmented Al could help South African company directors to diagnose complex business problems and recommend the relevant courses of action. ${ }^{33}$

The third option that South African directors could consider when integrating technology and their work is known as autonomous Al, which involves algorithms assuming human responsibilities as independent directors. ${ }^{34}$ Autonomous Al could eliminate human directors in South Africa and replace them with artificial entities or robo-directors. ${ }^{35}$ However, it would be difficult for autonomous Al to assume the full responsibilities of company directors considering South Africa's current legal framework, which allows only natural persons to be directors. ${ }^{36}$

Another hurdle that autonomous Al would need to overcome for it to replace human directors in South Africa is the issue of assigning personal liability in instances of non-compliance. ${ }^{37}$ Autonomous Al makes it difficult to determine the liability of the robo-directors, whether under contract or delict, since company decisions would be made by algorithms. ${ }^{38}$ Moreover, it remains to be seen whether the decision would be vested in the machine itself, the designer of the algorithm or the vendor. ${ }^{39}$ Additionally, the extent to which directors can delegate tasks to machines without exposing themselves to personal liability should be determined by regulators before autonomous Al takes over directors' decision making in South Africa. ${ }^{40}$ Furthermore, autonomous Al could eliminate some key aspects of board diversity such as gender, nationality and race, which are unique to natural persons, and this could improve the quality of

Petrin 2020 Colum Bus L Rev 984; Hilb 2020 JMG 9.

Petrin 2020 Colum Bus L Rev 982; Hilb 2020 JMG 9. For example, insurance companies in South Africa use Al to perform certain future calculations or administrative work. These companies use the same software that is used by most insurance companies around the world. Even though South Africa is not yet a developed country, South African companies are on an equal footing with the companies of other first-world countries.

Petrin 2020 Colum Bus L Rev 988; Hilb 2020 JMG 11.

Petrin 2020 Colum Bus $L$ Rev 988. However, autonomous Al can be a reality in 2030.

Petrin 2020 Colum Bus L Rev 988. Hilb 2020 JMG 11.

Section 69(7) of the Companies Act 2008.

Petrin 2020 Colum Bus L Rev 970-971. Hilb 2020 JMG 9.

Ameer-Mia, Pienaar and Kekana "South Africa" 257.

Petrin 2020 Colum Bus L Rev 982. Hilb 2020 JMG 9.

Petrin 2020 Colum Bus L Rev 970-971. Hilb 2020 JMG 9. 
decisions. ${ }^{41}$ However, an $\mathrm{Al}$ algorithm may not be able to simulate the emotional intelligence that comes with gender and race diversity. ${ }^{42}$

South African companies should employ augmented Al or synergic intelligence where natural persons and algorithms work together to enhance directors' independence and accountability. The incorporation of augmented Al fits well within the purposes of the Companies Act 2008. Section 5(1) of the Companies Act 2008 provides that the Act must be interpreted and applied in a manner that gives effect to the purposes set out in section 7 of the Companies Act 2008. Some of the purposes of the Companies Act 2008 include promoting the development of the South African economy by encouraging enterprise efficiency, encouraging transparency and high standards of corporate governance and balancing the rights and obligations of shareholders and directors in companies. ${ }^{43}$ Therefore, the use of augmented Al would encourage the balancing of shareholders and directors' rights and obligations in South Africa by minimising bias, since an algorithm's analysis cannot be influenced by the emotions of directors. Consequently, the use of augmented Al would enhance the independence of directors, since directors with dissenting opinions might be encouraged to contribute their views by simply relying on decision-support $\mathrm{Al}$ recommendations as the basis of their dissent. ${ }^{44}$ Furthermore, augmented Al allows an algorithm to generate initial recommendations on questions presented to it and such recommendations will be subject to the directors' approval. The directors can also provide additional insight into the algorithm's recommendations. ${ }^{45}$ Augmented Al entails that decision-making power remains vested in company directors in line with section 66(1) of the Companies Act 2008 to maintain the traditional separation of ownership and control dichotomy. ${ }^{46}$ In circumstances where the board of directors fails to explore other

41 The JSE listing requirement 3.84(i) states that the board of directors or the nomination committee, as the case may be, must have a policy on the promotion of gender diversity and the promotion of race diversity at board level. Also, directors' background and the environment can shape their approach to problems. Having directors of different races, nationality and gender on the board of directors therefore brings diversity to how they decide various corporate issues.

42 Petrin 2020 Colum Bus L Rev 1002; Viviers and Mans-Kemp 2019 IJDG 70.

43 Sections 7(b)(i) and (ii) of the Companies Act 2008.

44 Kamalnath 2020 Alb $L$ Rev 52 . Therefore, augmented Al and big data analytics would offer South African directors an opportunity to consider alternatives that might have been missed either due to time constraints, groupthink or structural bias.

45 Hilb 2020 JMG 11.

$46 \quad$ Also see Ameer-Mia, Pienaar and Kekana "South Africa" 255. 
alternatives, directors could consider the recommendations of the $\mathrm{Al}$ system. ${ }^{47}$

Due to its ability to analyse huge volumes of complex information in a very short space of time, decision-support Al can be employed by directors to align companies to the Companies Act 2008 and the relevant regulations so as to impartially protect several stakeholder interests. ${ }^{48}$ The Companies Act 2008 reflects a shift from the shareholder primacy approach to the enlightened shareholder value approach to corporate governance. ${ }^{49}$ The shareholder primacy approach has been criticised and blamed for the 2007-2008 global financial crisis (GFC) and the other corporate collapses that followed. ${ }^{50}$ It is argued that some of these corporate collapses were a direct result of the shareholder primacy approach. ${ }^{51}$ Augmented Al can easily cater for multiple stakeholder interests concurrently and it is not easily susceptible to bias.

Another form of digital technology that South African company directors could rely on to enhance independence is big data analytics. Big data refers to huge volumes of data which cannot be processed by the traditional data processing methods. ${ }^{52}$ For example, Walmart processes about 2.5 petabytes of data per hour from customer transactions. ${ }^{53}$ Big data analysis refers to analytics technology that stores, analyses and processes huge amounts of data in a short space of time to enhance decision making. ${ }^{54}$ It can also be defined as the employment of analytic techniques and technologies to analyse voluminous data in order to acquire valuable information for making decisions by directors. ${ }^{55}$ Big data analytics includes descriptive, predictive and prescriptive analytics. ${ }^{56}$

$47 \quad$ Kamalnath 2020 Alb L Rev 52.

48 Principle 8.3 of loDSA King IV Code; ss 7(a), (d) and (i) of the Companies Act 2008; Petrin 2020 Colum Bus L Rev 970.

$49 \quad$ Esser 2005 Obiter 722-723.

50 Mans-Kemp, Viviers and Collins 2018 IJDG 210.

51 United States Senate Role of the Board of Directors in Enron's Collapse concluded that one of the contributing factors to Enron's collapse was a lack of directors' independence. Motau and Kalema "Big Data Analytics Readiness" 2; Ridge, Johnston and Brian 2015 Afr J Bus Manage 688.

$53 \quad$ Ridge, Johnston and Brian 2015 Afr J Bus Manage 688.

54 Alalawneh and Alkhatib 2020 EJISDC 2; Motau and Kalema "Big Data Analytics Readiness" 2.

55 Ridge, Johnston and Brian 2015 Afr J Bus Manage 690.

56

Ridge, Johnston and Brian 2015 Afr J Bus Manage 690. According to Davenport descriptive analytics describe past events and are essentially a form of reporting, while predictive analytics employ statistical and other models on past data to create empirical predictions about the future, see Davenport 2015 The Wall Street Journal 1-3. South African company directors could employ predictive analytics to 
There is a need for companies to consider efficient ways of sorting out useful data from that which is useless since too much information is being generated nowadays from devices such as cellphones, laptops, radiofrequency identification tags, customer transactions and personal sensors. ${ }^{57}$

Big data analytics could improve corporate decision-making by directors in South Africa at all levels of a company including human resources, marketing, pricing, distribution and procurement. ${ }^{58}$ South African company directors could also apply big data analytics to gain competitive advantages inter alia through the determination of customer preferences regarding their real-time products and services. ${ }^{59}$ Therefore, it is submitted that real-time data analysis has become a major business resource for directors in South Africa. ${ }^{60}$ Nonetheless, most South African companies are yet to fully embrace the use of big data analytics for decision making and to realise its benefits regarding quality decisions. ${ }^{61}$ The Companies Act 2008 already provides a platform for employing big data analytics by allowing the storage of corporate information in electronic form. ${ }^{62}$ It is submitted that big data analytics and augmented Al could help South African company directors to process large volumes of information effectively and make informed decisions. ${ }^{63}$ If company directors are overwhelmed by the amount of information they have to consider before making a decision then they may fail to make an informed decision. ${ }^{64}$ In

make decisions pertaining to the probable consumer reaction to a new product or the expected sales volumes for their products. Davenport further states that prescriptive analytics combine data and algorithms to determine the best alternative to advance corporate performance by directors. South African company directors could use prescriptive analytics to decide whether or not to undertake certain projects taking into account the best interests of the account, see Davenport 2015 The Wall Street Journal 1. Alalawneh and Alkhatib 2020 EJISDC 2; Motau and Kalema "Big Data Analytics Readiness" 2 states that only processed data is useful for decision making. Alalawneh and Alkhatib 2020 EJISDC 2.

Mneney and Van Belle "Big Data Capabilities" 281.

ITWeb Staff Writer 2013 https://www.itweb.co.za/content/nkLgB1MebBbq59N4. In this regard, it is noted that JSE listed companies are better than unlisted companies. ITWeb Staff Writer 2013 https://www.itweb.co.za/content/nkLgB1MebBbq59N4. For example, s 1 of the Companies Act 2008 defines accounting records as information in written or electronic form concerning the financial affairs of a company. S 24(1)(a) of the Companies Act 2008 provides that any documents, accounts, books, writing, records or other information that a company is required to keep in terms of this Act or any other public regulation must be kept in written form, or other form or manner that allows that information to be converted into written form within a reasonable time. Kamalnath 2020 Alb L Rev 49. 
Australian Securities and Investments Commission (ASIC) v Healey, ${ }^{65}$ the respondent directors noted that some vital information was lost "in a very large board packet". ${ }^{66}$ Digital technologies like Al and big data could assist South African directors to keep and process crucial information in order to discharge their fiduciary and statutory obligations effectively and to enhance their independence.

Companies from almost every industry and sector are committed to exploiting data to gain a competitive advantage because technological advances in the Internet have made available huge amounts of data to the directors. ${ }^{67}$ The volume and diversity of data available to companies in South Africa cannot be analysed manually, and in most cases it exceeds the capacity of conventional databases. ${ }^{68}$ The ultimate goal of capturing, processing and analysing big data for company directors in South Africa should be to enhance decision-making through establishing trends in people and organisations from different perspectives. ${ }^{69}$ Some of the benefits of data-driven decision making which South African companies can enjoy if their directors employ big data analytics include higher market value, increased return on assets and equity, and optimum asset utilisation. ${ }^{70}$ Scholars such as Provost and Fawcett also submit that datadriven decision-making increases firm productivity by 4 to 6 percentage points. ${ }^{71}$ Some of the big data technologies that could be employed by company directors in South Africa to enhance decision making and independence include Hadoop, Hbase and CouchDB. ${ }^{72}$

However, Al can be subject to bias, which is usually a result of two factors. Firstly, Al bias can be a result of human bias; that is, it can be a product of the algorithm designer/programmer's preferences. ${ }^{73}$ This is known as designed bias. Designed bias could lead to distorted Al recommendations. Ultimately directors' independence will be compromised since they will be relying on biased Al recommendations. Al designers and programmers

65 Australian Securities and Investments Commission v Healey (No 2) [2011] FCA 1003.

66 Section 5(2) of the Companies Act 2008 provides that to the extent appropriate, a court interpreting or applying this Act may consider foreign company law.

67 Provost and Fawcett 2013 https://pubmed.ncbi.nlm.nih.gov/27447038/.

68 Provost and Fawcett 2013 https://pubmed.ncbi.nlm.nih.gov/27447038/; Ridge, Johnston and Brian 2015 Afr J Bus Manage 688. Subramaniam and Van Staden 2019 British Accounting Review 4. 
may deliberately develop software and algorithms to achieve certain intended goals. ${ }^{74}$ For example, since more men than women are involved in the production of algorithms, it has been alleged that Internet job searches have been biased towards men. ${ }^{75}$ Another practical example of designed bias relates to online retailers such as Amazon, which are capable of using differential pricing based on algorithm bias. ${ }^{76}$ The problem of designed bias can be addressed through public interest regulation, as $\mathrm{Al}$ should not be elevated to assume the position of an autonomous decision-maker that determines the price of goods and interest rates. ${ }^{77}$ The second source of algorithmic bias can be linked to the type of information fed into the system, since algorithms can process only the information that has been fed into them. ${ }^{78}$ If biased information is fed into the Al system, biased results will be produced. In the second scenario, correct and accurate data is key. ${ }^{79}$

Section 66(1) of the Companies Act 2008 provides that the business and affairs of a company must be managed by or under the direction of its board, which has the authority to exercise all of the powers and perform any of the functions of the company. ${ }^{80}$ Company directors are appointed to reduce shareholders' agency costs by monitoring and scrutinising corporate management's conduct to ensure that they act in the company's best interests. ${ }^{81}$ The current unpredictable economic landscape coupled with some recent corporate challenges has led to high demand for competent directors in South Africa. ${ }^{22}$ As a result, reputable directors tend to serve on several boards at the same time. ${ }^{83}$ The problem of busy directors is further compounded by the fact that South Africa has a limited pool of eligible black female directors. ${ }^{84}$ Furthermore, legislation such as

\footnotetext{
74 Dignam 2020 Cambridge J Reg Econ Soc 42. Hilb 2020 JMG 10.

75 Dignam 2020 Cambridge J Reg Econ Soc 39.

76 Dignam 2020 Cambridge J Reg Econ Soc 42.

77 Dignam 2020 Cambridge J Reg Econ Soc 43.

78 Hilb 2020 JMG 10; Petrin 2020 Colum Bus L Rev 1005.

79 Hilb 2020 JMG 15; Petrin 2020 Colum Bus L Rev 1005.

80 Section 66(1) of the Companies Act 2008.

81 Terjesen, Couto and Francisco 2016 JMG 449; Viviers and Mans-Kemp 2019 IJDG 69; Mans-Kemp, Viviers and Collins 2018 IJDG 210; McNamee, Misha and Bouwer Fine Line between "Overboarded" and Overburdened 4; OECD Principles of Corporate Governance Art IV. McNamee, Misha and Bouwer Fine Line between "Overboarded" and Overburdened 3.

McNamee, Misha and Bouwer Fine Line between "Overboarded" and Overburdened 8; Chiranga and Chiwira 2014 Economics World 379; Jiraporn, Singh and Lee 2009 JBF 820. 
the Broad-Based Black Economic Empowerment Act ${ }^{85}$ has further restricted the pool of qualifying directors by demanding the inclusion of directors from historically disadvantaged backgrounds. ${ }^{86}$ A director who serves on multiple boards simultaneously can be described as an interlocked or a busy director. ${ }^{87}$ Busy directors' independence might be compromised due to the possibility of their having conflicting interests because of their numerous connections and interests.

There is no statutory limitation on how many boards a company director can serve on in South Africa. ${ }^{88}$ This allows company directors to serve on as many boards as they want, and this could inadvertently impair their independence. The King IV Code $2016^{89}$ and the JSE listing requirements are also silent on this issue. ${ }^{90}$ However, there seems to be a local and international academic consensus that when a director serves on more than three boards concurrently, he or she is busy. ${ }^{91}$ Almost a third of South Africa's 100 largest JSE-listed companies' directors are busy. ${ }^{92}$ Busy directors face time constraints and tend to be too busy to discharge their duties effectively, which may affect the quality of their decisions. ${ }^{93}$

85 Sections 2(b) and (d) of the Broad-Based Black Economic Empowerment Act 53 of 2003 provide that this Act seeks, inter alia, to achieve "a substantial change in the racial composition of ownership and management structures and in the skilled occupations of existing and new enterprises and to increase the extent to which black women own and manage existing and new enterprises". McNamee, Misha and Bouwer Fine Line between "Overboarded" and Overburdened 2.

87 Viviers and Mans-Kemp 2019 IJDG 68; Mans-Kemp, Viviers and Collins 2018 IJDG 212; Chiranga and Chiwira 2014 Economics World 379; McNamee, Misha and Bouwer Fine Line between "Overboarded" and Overburdened 3. Mans-Kemp, Viviers and Collins 2018 IJDG 210; McNamee, Misha and Bouwer Fine Line between "Overboarded" and Overburdened 4.

89 JSE listing requirement 3.84 states that the effect of incorporating certain practices from the King Code in the Listings Requirements is to make their implementation mandatory. Additionally, it has to be noted that the courts keep developing the law relating to the enforceability of loDSA King IV Code principles (Part 3). In this respect, the North Gauteng High Court in the case of OUTA NPC v Myeni 2019 ZAGPPHC 957 (12 December 2019) averred that in future, courts may refer to IoDSA King IV Code to determine directors' compliance with their fiduciary duties. Also see SABC v Mpofu 20094 All SA 169 (GSJ) para 61, where the court held that the boards of directors of public companies are enjoined to consider their responsibilities in terms of the King Report. McNamee, Misha and Bouwer Fine Line between "Overboarded" and Overburdened 2. Viviers and Mans-Kemp 2019 IJDG 68; Mans-Kemp, Viviers and Collins 2018 IJDG 210; McNamee, Misha and Bouwer Fine Line between "Overboarded" and Overburdened 3, 4.

92 Viviers and Mans-Kemp 2019 IJDG 75.

93 Mans-Kemp, Viviers and Collins 2018 IJDG 213; Viviers and Mans-Kemp 2019 IJDG 68; McNamee, Misha and Bouwer Fine Line between "Overboarded" and Overburdened 3. 
Busy directors usually miss board meetings, thus weakening the board's monitoring role and ultimately leading to ineffective corporate governance. ${ }^{94}$ Empirical research conducted on almost 200 South African listed companies revealed that there is a strong positive relationship between the frequency of company board meetings and corporate performance..$^{95}$ Consequently, it follows that if a director misses some board meetings then the company's performance will be negatively affected. The independence of busy directors is questionable in that sometimes, due to time constraints, they may fail to consider all the relevant information before making a decision. Ultimately this results in conflicts of interest being overlooked, thereby impairing directors' independence. Big data analytics may assist and create more time for busy directors by processing huge amounts of corporate data in a short space of time.

\subsection{Technology and the independence of company directors}

The ability of directors to discharge their duties independently is one of the pillars of corporate governance in South Africa. ${ }^{96}$ In South Africa all company directors are expected to exercise an independent judgment in their decisions and to act in the best interests of the company when discharging their duties. ${ }^{97}$ The independence of company directors includes the exercise of objective, unfettered judgment, and the absence of an interest, position, association or relationship which, when judged from the perspective of a reasonable and informed third party, is likely to cause directors to be biased in decision-making. ${ }^{98}$ The agency theory of corporate governance states that one of the traditional and primary ways to strengthen the independence of company directors is by including nonexecutive directors on the board. ${ }^{99}$

$94 \quad$ Viviers and Mans-Kemp 2019 IJDG 70; Mans-Kemp, Viviers and Collins 2018 IJDG 210-211; McNamee, Misha and Bouwer Fine Line between "Overboarded" and Overburdened 4; Chiranga and Chiwira 2014 Economics World 379; Jiraporn, Singh and Lee 2009 JBF 820. Ntim and Osei 2011 AREF 97. Also see Chiranga and Chiwira 2014 Economics World 379; Jiraporn, Singh and Lee 2009 JBF 820. Section 76(3) of the Companies Act 2008; Principle 7 of part 5.3 of loDSA King IV Code. Section 76(3)(b) of the Companies Act 2008; Principle 7 of part 5.3 of loDSA King IV Code.

98 Section 76(2)-(4) of the Companies Act 2008; Part 1 of loDSA King IV Code.

99 Rosenstein and Wyatt 1997 Journal of Financial Economics 229-250; Terjesen, Couto and Francisco 2016 JMG 459; loDSA King IV Code. However, it is noteworthy that the Companies Act 2008 does not differentiate between executive and non-executive directors. See ss 1 and 76(1) of the Companies Act 2008. The 
The King IV Code 2016 does not specifically prescribe the number of nonexecutive directors corporate boards should have except to state that the board should comprise a majority of non-executive members, most of whom should be independent. ${ }^{100}$ The King IV Code 2016 further calls for company boards to comprise of an appropriate number of independent directors to improve company directors' independence. ${ }^{101}$ What is appropriate depends on the circumstances of each company, taking into consideration factors such as the company's capacity, resources and impact. ${ }^{102}$ Furthermore, all companies whose securities are publicly traded on the JSE are required to either have an independent non-executive board chairman or to appoint a lead independent director to enhance corporate independence. ${ }^{103}$

Although companies with more independent directors tend to be more profitable than those with fewer independent directors. Petrin and Kamalnath argue that the longer independent directors stay in a company, the more they lose their independence. ${ }^{104}$ Independent directors usually serve long terms and this sometimes create collegiality and even friendships with other executive directors, which affects their independence. ${ }^{105}$ Groupthink and structural biases or friendships could undermine the independence of company directors. ${ }^{106}$ This will ultimately affect the quality of decisions made. One way of minimising groupthink

only executive director the Companies Act 2008 makes reference to is one who is appointed in terms of $\mathbf{s} 200$ of the Companies Act 2008 to lead the Takeover and Regulations Panel. The JSE listing requirement 3.84(e) defines executive directors as those that are involved in the management of the company and/or in full-time salaried employment whereas non-executive directors are neither involved in the day-to-day management of the business nor are they full-time salaried employees. Regarding diversity, there has been a gradual increase in studies advocating for race and gender diversity on company boards as another tool to enhance directorial independence. For more on this see Terjesen, Couto and Francisco 2016 JMG 453. Principle 7 of part 5.3 of loDSA King IV Code recommends that the board should set targets for race and gender representation in its membership.

100 Principle 7 of part 5.3 of loDSA King IV Code.

101 Principle 7 of part 5.3 of loDSA King IV Code.

102 Principle 7 of part 6.5 of loDSA King IV Code takes cognizance of the fact that some companies might not afford the services of independent non-executive directors due to resource constraints. To counter this, the King IV Code encourages companies to consider consulting with experienced and competent executive directors on an ad hoc basis and inviting them to attend board meetings when the need arises.

103 JSE listing requirement 3.84 states that the effect of incorporating certain practices from the King Code in the Listings Requirements is to make their implementation mandatory.

104 Petrin 2020 Colum Bus L Rev 1005; Kamalnath 2020 Alb L Rev 48. See also Muniandy and Hillier 2015 Pacific-Basin Finance Journal 122.

105 Petrin 2020 Colum Bus L Rev 1005.

106 Petrin 2020 Colum Bus L Rev 1005. 
and structural bias is the integration and reliance on augmented $\mathrm{Al}$ and big data analytics. An Al decision support system will be influenced by data and not by feelings of collegiality. ${ }^{107}$

Information asymmetry also negatively affects non-executive directors' monitoring and advisory roles, since they are not involved in the daily management of the company. ${ }^{108}$ Furthermore, the independence of directors in South Africa could be compromised by structural bias, corruption and the presence of financial interest. ${ }^{109}$ Since augmented $\mathrm{Al}$ minimises human weaknesses, it could improve the independence of company directors by reducing agency costs in corporate management. ${ }^{110}$ The independence of company directors is a key corporate governance tool which could counter agency costs. ${ }^{111}$ Augmented Al could deal with structural bias among company directors in South Africa. ${ }^{112}$

The business and affairs of a company must be managed by or under the direction of its board of directors. ${ }^{113}$ The board of directors has the authority to exercise all of the powers and perform any of the functions of the company. ${ }^{114}$ Exercising such responsibility entails that directors perform various fiduciary duties to the company. ${ }^{115}$ Directors' duties have now been partially codified in South Africa to enhance legal certainty. ${ }^{116}$ Breach of the common law and statutory provisions on directors' fiduciary duties may result in the relevant director incurring personal liability. ${ }^{117}$ Apart from the directors' duties found in the Companies Act 2008 South African directors also need to adhere to additional requirements set out in regulations and best practice directives such as the JSE listing rules and corporate governance principles. ${ }^{118}$ These regulations are additional

\footnotetext{
107 Kamalnath 2020 Alb L Rev 52.

108 Muniandy and Hillier 2015 Pacific-Basin Finance Journal 113.

109 Sections 75 and 76(2) of the Companies Act 2008; Petrin 2020 Colum Bus L Rev 1005.

110 Section 76(3) of the Companies Act 2008; Kamalnath 2020 Alb L Rev 43.

111 Kamalnath 2020 Alb $L$ Rev 45. It is noteworthy that purchasing Al could be very expensive as well. Therefore, companies may make monthly instalments to pay for Al.

Kamalnath 2020 Alb L Rev 45.

Section 66(1) of the Companies Act 2008.

Section 66(1) of the Companies Act 2008.

Sections 76(2) and (3) of the Companies Act 2008; Van Tonder 2018 Obiter 303.

116 Sections 75, 76 and 77(2) of the Companies Act 2008; Cassim 2019 Stell LR 212 who further notes that those partial codification of the directors' duties means that common law duties that have not been expressly replaced by the Act remain applicable. Also see Van Tonder 2018 Obiter 302-303.

117 Sections 77(2)(a) and (b) of the Companies Act 2008.

118 JSE listing requirement 3.84.
} 
attempts to ensure that directors discharge their duties effectively. ${ }^{119}$ Directors must fully consider all the statutory provisions and other selfregulatory mechanisms before making any decision. Failure to comply with the provisions of the Companies Act 2008 could lead to the personal liability of the affected company directors. ${ }^{120}$

In the aftermath of the GFC, the boards of some companies were found to have failed to adequately exercise independent judgement in their decisions. ${ }^{121}$ Previous discussions on the independence of company directors seem to have focussed more on financial interest, probably due to the shareholder wealth maximisation approach. ${ }^{122}$ However, it must be noted that directors need to be intellectually and psychologically independent to perform their duties optimally. ${ }^{123}$ The presence of independent directors on the board and various committees has not always added the expected value due to information asymmetry and structural bias. ${ }^{124}$ Furthermore, company directors usually have to make important decisions in a short space of time and independent directors might not be able to read through all the relevant information on short notice. ${ }^{125}$ Being de facto corporate outsiders, independent directors face constraints as they usually serve on several boards of companies concurrently. ${ }^{126}$ The integration of $\mathrm{Al}$ and big data analytics could enhance director independence by minimising bias in decision making.

\subsection{Technology and the accountability of company directors}

Accountability occurs when a party is held responsible for something and is able to explain its actions and/or decisions. ${ }^{127}$ According to the agency theory of corporate governance, directors should be accountable to the company shareholders. The accountability of company directors is one of

\footnotetext{
119 Section 5(6) of the Companies Act 2008; Kamalnath 2020 Alb L Rev 48.

120 Section 77 of the Companies Act 2008.

121 United States Senate Role of the Board of Directors in Enron's Collapse.

122 Section 75 of the Companies Act 2008; Kamalnath 2020 Alb L Rev 48.

123 Part 1 of loDSA King IV Code; Kamalnath 2020 Alb L Rev 48.

124 Kamalnath 2020 Alb L Rev 48.

125 Kamalnath 2020 Alb $L$ Rev 48. Principle 1 of part 5.1 of loDSA King IV Code and ss 76(4)(a)(i) and (b) of the Companies Act 2008 require company directors to adequately prepare for meetings.

126 Kamalnath 2020 Alb $L$ Rev 48. However, this does not suggest that independent directors are the only ones who serve on several boards of directors. The emphasis on independent directors stems from the fact that they are the ones who usually enhance corporate independence.

127 Part 1 of IoDSA King IV Code; Hilb 2020 JMG 9.
} 
the key principles of corporate governance in South Africa. ${ }^{128}$ There are various internal and external accountability mechanisms which companies in South Africa can employ to enhance director accountability. Shareholders' power to appoint and remove directors is one of the primary accountability mechanisms employed by companies in South Africa. ${ }^{129}$ The ability of shareholders to amend the memorandum of incorporation and access to shareholder meeting minutes are further accountability mechanisms. ${ }^{130}$ Board meeting frequency, adequate reporting and easy circulation of corporate information, access to the shareholders' register, and directors' ability to request a meeting at any time are additional director accountability mechanisms. ${ }^{131}$

The liability of company directors in South Africa stems from their accountability. ${ }^{132}$ In turn, director accountability emanates from the duties directors owe to the company. The Companies Act 2008 has enhanced directors' accountability by partially codifying the directors' duties, and a breach of these duties will result in liability. ${ }^{133}$ These duties arise from the fact that directors hold a fiduciary relationship to the company and shareholders. ${ }^{134}$ The Companies Act 2008 provides that a company director must act with a degree of care, skill and diligence. ${ }^{135}$ The requirement of diligence is a novel addition to the directors' partially codified duties of care and skill. ${ }^{136}$ Diligence implies caution and attention. ${ }^{137}$ Therefore, a diligent director attends board meetings, pays attention to relevant paperwork and is devoted to the company's business, affairs and practices. ${ }^{138} \mathrm{Al}$ could be integrated into South African corporate governance to enhance director diligence by compiling notes during board

128 Part $\mathrm{C}$ of Chapter two of the Companies Act 2008; part 1 of loDSA King IV Code; Hilb 2020 JMG 9.

129 Sections 68 and 71 of the Companies Act 2008.

130 Section 24(3)(d) of the Companies Act 2008.

131 Section 73(1)(a) of the Companies Act 2008 states that a director authorised by the board of a company may call a meeting of the board at any time. South African companies could employ prescriptive analytics to prepare reports and financial statements. This would enhance director accountability by ensuring that information is readily available to the various corporate stakeholders.

132 Section 77 of the Companies Act 2008; Hilb 2020 JMG 9.

133 Section 77 of the Companies Act 2008. Also see Hilb 2020 JMG 9.

134 However, in the recent case of Hlumisa Investment Holdings (RF) Limited $v$ Kirkinis 20194 SA 569 (GP) para 91, it was held that the special remedy provided for in $\mathrm{s}$ 77(2) of the Companies Act 2008 with respect to the contravention of s 76(3) of the same Act emanates from a fiduciary duty to the company and not to shareholders.

135 Section 76(3)(c) of the Companies Act 2008.

136 Section 76(3)(b) of the Companies Act 2008; Van Tonder 2018 Obiter 306.

137 Garner et al Black's Law Dictionary 1375.

138 Sections 66(1), 73 and 76(4)(b) of the Companies Act 2008; Charitable Corporation v Sutton (1742) 26 ER 642; Van Tonder 2018 Obiter 306. 
meetings and could help company secretaries schedule meetings and prepare reports for directors. ${ }^{139}$

Since the Companies Act 2008 already allows the storage of company information in electronic form, it is submitted that a diligent director could employ digital technologies such as augmented Al and big data analytics to discharge his or her duties well. ${ }^{140}$ The duty of care and diligence entails an objective test whilst the duty of skill requires a subjective test, since the type of skills that individuals possess differ from person to person. ${ }^{141}$ Considering the amount of information that is available in this technology-driven age, it is not far-fetched for the courts to consider the objective test of section 76(3)(c) of the Companies Act 2008 to include the fact that a reasonable director would rely on augmented $\mathrm{Al}$ and big data analytics when discharging his duties. It is submitted that section 76(3)(c) of the Companies Act 2008 is wide enough to allow the integration and reliance on technology by company directors.

Another important aspect that is closely linked to the directors' duties in section 76(3)(c) of the Companies Act 2008 is the business judgment rule. The business judgment rule is provided for in section 76(4)(a)(i) of the Companies Act 2008. This provision states that a director will have satisfied the obligations of subsections (3)(b) and (c) of the Companies Act 2008 if the director has taken reasonably diligent steps to become informed about the matter. ${ }^{142}$ Company directors in South Africa are obliged to have all relevant material information available to them before making a decision. ${ }^{143}$ The business judgment rule states that directors are not liable for corporate harm arising from mere errors of judgment if they acted in good faith in the best interests of the company. ${ }^{144} \mathrm{~A}$ director who acts in the best interests of a company exercises independent judgment. South African company directors could integrate and use Al measures to enhance their independence. The business judgment rule protects honest directors from hindsight bias and presents the decision-making function of the duty of care, skill and diligence as a measure of directors' conduct. ${ }^{145}$

\footnotetext{
139 Section 88 of the Companies Act 2008; Petrin 2020 Colum Bus L Rev 981.

140 See $\mathrm{s} 1$ of the Companies Act 2008 for the definition of accounting records read together with s 24(1)(a) of the same Act.

141 Mongalo 2016 Journal of Corporate and Commercial Law \& Practice 5-6; Du Plessis 2010 Acta Juridica 263-289.

142 Section 76(4)(a)(i) of the Companies Act 2008; Cassim et al Contemporary Company Law 508.

143 Section 76(4)(i) of the Companies Act 2008; Kamalnath 2020 Alb L Rev 47.

144 Section 76(4) of the Companies Act 2008; Havenga 2000 SA Merc LJ 28-30.

145 Section 76(4) of the Companies Act 2008; Cassim et al Contemporary Company Law 565; Havenga 2000 SA Merc LJ 28; Van Tonder 2018 Obiter 302-316.
} 
One of the underlying values of the business judgment rule is the fallibility of people and the recognition that directors have limited memories and computational skills. ${ }^{146}$ By integrating and relying on augmented $\mathrm{Al}$ and data analytics, South African directors would make better quality and better-informed decisions through leveraging the superior computational and analytical capabilities of technology.

Company directors may struggle to take into account all the relevant corporate governance principles and other voluminous published articles before making decisions due to time constraints. One of the excellent digital technology systems that company directors could employ to enhance their independence and accountability is IBM Watson's (Watson) cognitive computing systems. ${ }^{147}$ Watson is already being used by companies in some first-world countries for medical diagnosis, financial advice and legal due diligence. ${ }^{148}$ In Sweden, Standard Bank uses Watson to address customer queries. ${ }^{149}$ Watson is versatile since a director can communicate with it through voice, image and text, without internet connection. ${ }^{150}$ With such capabilities, Watson can be employed as a platform to interact with or account to various corporate stakeholders. Directors can feed corporate information into Watson and stakeholders can access it anytime. Stakeholders can ask Watson any question related to their company and get their responses in real-time. Shareholders can access minutes of the annual general meetings more conveniently. They can further ask the algorithm any question concerning the contents of the meeting and it will explain it to them.

Watson's ability to process natural language facilitates advanced interaction between human beings and algorithms which can assist South African company directors to make better decisions. ${ }^{151}$ Watson is

146 Bainbridge 2004 Vand L Rev 121

147 Guidi 2016 Future Internet 1-16; Chen, Argentinis and Weber 2016 Clinical Therapeutics 690, defines cognitive computing as an element of digital technologies that can perform human acts such as reading, reasoning and learning, and that have the ability to draw inferences from large sets of unstructured data.

148 Petrin 2020 Colum Bus L Rev 982; Dignam 2020 Cambridge J Reg Econ Soc 4142.

149 Memeti and Pllana 2018 Journal of Computational Science 276.

150 Memeti and Pllana 2018 Journal of Computational Science 276; Collinaszy, Bundzel and Zolotova 2017 Acta Electrotechnica et Informatica 58.

151 Memeti and Pllana 2018 Journal of Computational Science 276; High 2012 https://developer.ibm.com/watson/wp-content/uploads/sites/19/2013/11/The-Eraof-Cognitive-Systems-An-Inside-Look-at-IBM-Watson-and-How-it-Works. pdf 2-3. 
designed to integrate and analyse huge volumes of data. ${ }^{152}$ It can teach itself a new subject from both structured and unstructured data by categorising related information in its database. ${ }^{153}$ When asked a question or presented with a scenario, Watson searches its database to generate and evaluate hypotheses to provide an answer. ${ }^{154}$ Company directors could feed information into Watson and it would categorise it into financial statements, annual meeting reports, notices of meetings, minutes of meetings and so forth. ${ }^{155}$ Various stakeholders could access the information that they are legally entitled to access. ${ }^{156}$ Easy access to company records through augmented Al would enhance directors' accountability in South Africa. As a cognitive system, Watson can comprehend technical, industry-specific nomenclature and apply advanced reasoning, predictive modelling and machine learning procedures to advance research in real time. ${ }^{157}$ In essence, Watson simulates aspects of human thought processes to analyse large volumes of data in a very short space of time and without bias. ${ }^{158}$ Unbiased recommendations from Watson would promote directorial independence. Empirical research by Hamilton et al has shown that the use of decision support tools such as Watson is cost-effective and improves the quality of the decisions made. ${ }^{159}$

\subsection{Do boards of South African company directors need technology experts?}

Quality informed decisions at board level are a result of accurate expert advice. Some companies such as Kodak, which at some point seemed to be too big to sink, came to an unprecedented demise because they could not keep up with technological changes. ${ }^{160}$ Technology governance has become so essential to business models and practices that it should be

152 Chen, Argentinis and Weber 2016 Clinical Therapeutics 688; Doyle-Lindrud 2015 Clin J Oncol Nurs 31.

153 Examples of structured data include data kept according to some specific fields in spreadsheets and other relational databases, whilst unstructured data refers to raw data such as images, text, audio and video recordings. See Ridge, Johnston and Brian 2015 Afr J Bus Manage 689. Memeti and Pllana 2018 Journal of Computational Science 276; Collinaszy, Bundzel and Zolotova 2017 Acta Electrotechnica et Informatica 59; Doyle-Lindrud 2015 Clin J Oncol Nurs 31.

155 Section 26(1) of the Companies Act 2008.

156 Sections 26(2) and (3) of the Companies Act 2008.

157 Chen, Argentinis and Weber 2016 Clinical Therapeutics 688.

158 Chen, Argentinis and Weber 2016 Clinical Therapeutics 690; Doyle-Lindrud 2015 Clin J Oncol Nurs 31.

159 Hamilton et al $2019 \mathrm{~J}$ Oncol Pract 277.

160 Valentine and Stewart 2013 IJDG 347. 
elevated to board level in South Africa. ${ }^{161}$ Issues such as business stability and disaster recovery require technological expertise at board level. ${ }^{162}$ To be able to make quality decisions, directors must be able to ask the right questions when presented with technology-related proposals. ${ }^{163}$ One of the accountability mechanisms in South African corporate governance is an annual general meeting (AGM). An AGM presents a platform for shareholders to question directors regarding the business and affairs of the company. A technology expert at board level could enhance the directors' accountability to the shareholders at AGMs. The use of Al measures could enhance the disclosure of relevant information to all the corporate stakeholders at AGMs. ${ }^{164}$

Companies have traditionally opted to rely entirely on general technical advisers for technology-related aspects. ${ }^{165}$ Consequently, companies have not bothered to have a technology expert on their boards of directors. ${ }^{166}$ This presents a challenge, however, since the absence of a technology expert at company director level deprives the board of informed decisions regarding technological matters. ${ }^{167}$ As companies in South Africa adopt the above-mentioned technologies such as big data analytics, descriptive analytics, prescriptive analytics and cognitive systems, there is a need to have a technology expert at board level who understands such technology. A technology expert could contribute to the enhancement of director accountability and independence in South Africa. According to the resource-based theory (RBT), distinctiveness and competitive advantage is a result of a gradual development of dynamic competences, in this case, the technological capabilities of the relevant company. ${ }^{168}$

The adoption of digital technologies such as Al and big data as suggested above requires a technological expert at board level to effectively enhance company directors' independence and accountability. It is submitted that companies in South Africa should elect technology experts to the board of company directors on a rotational basis rather than relying on general technical advisors, who in most cases offer merely general advice. ${ }^{169}$

Andriole 2009 CAIS 375.

Andriole 2009 CAIS 375.

Valentine and Stewart 2013 IJDG 348.

Valentine and Stewart 2013 IJDG 348.

Bravard 2015 https://hbr.org/2015/09/all-boards-need-a-technology-expert.

Bravard 2015 https://hbr.org/2015/09/all-boards-need-a-technology-expert.

Bravard 2015 https://hbr.org/2015/09/all-boards-need-a-technology-expert.

Barney et al "Role of Resource-Based Theory in Strategic Management Studies" 112.

169 Bravard 2015 https://hbr.org/2015/09/all-boards-need-a-technology-expert; Andriole 2009 CAIS 374. 
General technical advisors focus only on ensuring that companies are performing better than their rivals. ${ }^{170}$

\section{Concluding remarks}

The integration and reliance on technology by company directors in South Africa to enhance their independence and accountability is necessary to keep up with the dynamic and data-driven nature of contemporary society. A combination of digital technologies such as $\mathrm{Al}$, cloud computing, big data analytics and cognitive systems has the potential to improve director accountability and independence in South Africa. Other possible benefits of incorporating technology into the South African corporate governance structure include greater market value, increased return on assets and equity, and optimum asset utilisation. ${ }^{171}$ The Companies Act 2008 generally allows directors to rely on technology to enhance their independence and accountability. For example, sections 1 and 24(1)(a) of the Companies Act 2008 allow companies to keep board minutes and any other documents in electronic or any other format for seven years. This facilitates the use of big data analytics and other decision-support tools to enhance company directors' independence and accountability.

As established above, there are some loopholes in current South African company law regarding the independence and accountability of company directors. It is submitted that the lack of proper guidance in terms of the Companies Act 2008 and self-regulatory instruments such as the King Codes allows directors to serve on numerous boards of directors. This results in busy directors who often face time constraints, and their independence may be compromised in the process. Moreover, the lack of trust in Al measures could be another barrier to the use of technological measures to enhance company directors' accountability and independence in South Africa. Difficulties in accessing company records by stakeholders may also undermine company directors' accountability. Human fallibility and natural computational limitations are some of the weaknesses of company directors that may result in a call for augmented Al to improve their decision making.

Given the flaws described above, it is recommended that there should be a clear provision in the Companies Act 2008 regarding the maximum number of boards that a director can serve on concurrently. This could be done through a legislative amendment to the Companies Act 2008. It is

$\begin{array}{ll}170 & \text { Bravard } 2015 \text { https://hbr.org/2015/09/all-boards-need-a-technology-expert. } \\ 171 & \text { Provost and Fawcett } 2013 \text { https://pubmed.ncbi.nlm.nih.gov/27447038/. }\end{array}$ 
further recommended that all companies should integrate and utilise innovative technology to enhance the accountability and independence of directors in South Africa. Furthermore, Al and other innovative technological measures could promote the accountability of directors by making corporate records more readily available to all the relevant stakeholders. It is also submitted that the Institute of Directors of South Africa (IoDSA) should conduct regular technological literacy workshops and seminars that are mainly aimed at equipping directors, with the relevant knowledge and skills. This could ensure that company directors keep up with any latest decision-making support technologies. Additionally, such educational programmes by the IoDSA could also help to encourage company directors to learn to trust and utilise Al measures when executing their duties and responsibilities.

It is further recommended that all South African companies should appoint a technological expert to their boards of directors. Board chairpersons should also evaluate their companies' preparedness to handle technological integration by mapping the technological expertise required to their current non-executive directors' pool. ${ }^{172}$ This should be done to determine if there is anyone from the current board who qualifies to be a technological expert or if there is a need to hire someone external. However, some small companies might not possess the financial capacity to acquire the services of a technology expert. In this regard, it is submitted that such companies might commence by inviting experts in technology to attend their board meetings on an ad hoc basis until such a time as they are capable of appointing a full-time technology expert.

\section{Bibliography}

\section{Literature}

Ameer-Mia, Pienaar and Kekana "South Africa"

Ameer-Mia F, Pienaar C and Kekana N "South Africa" in Berkowitz M (ed) $A$, Machine Learning and Big Data $2^{\text {nd }}$ ed (Global Legal Group Ltd London 2020) 248-260

Alalawneh and Alkhatib 2020 EJISDC

Alalawneh AAF and Alkhatib SF "The Barriers to Big Data Adoption in Developing Economies" 2020 EJISDC 1-16

172 Bravard 2015 https://hbr.org/2015/09/all-boards-need-a-technology-expert. 
Andriole 2009 CAIS

Andriole SJ "Boards of Directors and Technology Governance: The Surprising State of the Practice" 2009 CAIS 373-394

Bainbridge 2004 Vand L Rev

Bainbridge SM "The Business Judgment Rule as Abstention Doctrine" 2004 Vand L Rev 83-130

Barney et al "Role of Resource-Based Theory in Strategic Management Studies"

Barney JB et al "The Role of Resource-Based Theory in Strategic Management Studies: Managerial Implications and Hints for Research" in Dagnino GB (ed) Handbook of Research on Competitive Strategy (Edward Elgar Cheltenham 2012) 109-146

Brennan, Subramaniam and Van Staden 2019 British Accounting Review Brennan NM, Subramaniam N and Van Staden CJ "Corporate Governance Implications of Disruptive Technology: An Overview" 2019 British Accounting Review 1-15

Cassim et al Contemporary Company Law

Cassim FHI et al Contemporary Company Law $2^{\text {nd }}$ ed (Juta Claremont 2012)

Cassim 2019 Stell LR

Cassim R "An Analysis of Directors' Fiduciary Duties in the Removal of a Director from Office" 2019 Stell LR 212-233

Chen, Argentinis and Weber 2016 Clinical Therapeutics

Chen Y, Argentinis E and Weber G "IBM Watson: How Cognitive Computing can be Applied to Big Data Challenges in Life Sciences Research" 2016 Clinical Therapeutics 688-701

Chiranga and Chiwira 2014 Economics World

Chiranga $\mathrm{N}$ and Chiwira $\mathrm{O}$ "Impact of Multiple Directorships on Performance for Companies Listed on the Johannesburg Stock Exchange (JSE)" 2014 Economics World 378-387

Collinaszy, Bundzel and Zolotova 2017 Acta Electrotechnica et Informatica Collinaszy J, Bundzel $\mathrm{M}$ and Zolotova I "Implementation of Intelligent Software Using IBM Watson and Bluemix" 2017 Acta Electrotechnica et Informatica 58-63 
Davenport 2015 The Wall Street Journal

Davenport TH "The Rise of Automated Analytics" 2015 The Wall Street Journal 1-3

Dignam 2020 Cambridge J Reg Econ Soc

Dignam A "Artificial Intelligence, Tech Corporate Governance and the Public Interest Regulatory Response" 2020 Cambridge J Reg Econ Soc 37-54

Doyle-Lindrud 2015 Clin J Oncol Nurs

Doyle-Lindrud S "Watson will See You Now: A Supercomputer to Help Clinicians Make Informed Treatment Decisions" 2015 Clin J Oncol Nurs 31-32

Du Plessis 2010 Acta Juridica

Du Plessis JJ "A Comparative Analysis of Directors' Duty of Care, Skill and Diligence in South Africa and in Australia" 2010 Acta Juridica 263-289

Esser 2005 Obiter

Esser I "The Enlightened Shareholder Value Approach Versus Plurism in the Management of Companies" 2005 Obiter 719-725

Garner et al Black's Law Dictionary

Garner BA et al Black's Law Dictionary $8^{\text {th }}$ ed (Thomson West St Paul 2004)

Guidi et al 2016 Future Internet

Guidi G et al "Case Study: IBM Watson Analytics Cloud Platform as Analytics-as-a-Service System for Heart Failure Early Detection" 2016 Future Internet 1-16

Hamilton et al $2019 \mathrm{~J}$ Oncol Pract

Hamilton JG et al "'A Tool, not a Crutch': Patient Perspectives about IBM Watson for Oncology Trained by Memorial Sloan Kettering" $2019 \mathrm{~J} \mathrm{Oncol}$ Pract 277-288

Havenga 2000 SA Merc LJ

Havenga MK "The Business Judgment Rule - Should We Follow the Australian Example?" 2000 SA Merc LJ 25-37

Hilb 2020 JMG

Hilb M "Toward Artificial Governance? The Role of Artificial Intelligence in Shaping the Future of Corporate Governance" 2020 JMG 1-20 
IoDSA King III Code

Institute of Directors in Southern Africa The King Code on Corporate Governance in South Africa III (IoDSA Parklands 2009)

loDSA King IV Code

Institute of Directors in Southern Africa The King Report/Code on Corporate Governance in South Africa IV (IoDSA Parklands 2016)

Jiraporn, Singh and Lee $2009 \mathrm{JBF}$

Jiraporn $P$, Singh $M$ and Lee $C$ "Ineffective Corporate Governance: Director Busyness and Board Committee Memberships" 2009 JBF 819828

Kamalnath 2020 Alb L Rev

Kamalnath A "The Perennial Quest for Board Independence: Artificial Intelligence to the Rescue?" 2020 Alb L Rev 43-60

Liu and Lin 2020 Harv Int'I LJ

Liu $\mathrm{H}$ and Lin C "Artificial Intelligence and Global Trade Governance:

Pluralist Agenda" 2020 Harv Int'l LJ 407-450

Mans-Kemp, Viviers and Collins 2018 IJDG

Mans-Kemp N, Viviers $S$ and Collins $S$ "Exploring the Causes and Consequences of Director Overboardedness in an Emerging Market" 2018 IJDG 210-220

McNamee, Misha and Bouwer Fine Line between "Overboarded" and Overburdened

McNamee M, Misha T and Bouwer C Whitepaper: The Fine Line between "Overboarded" and Overburdened: Critical Factors Impacting the Effectiveness of "Busy Directors" in South Africa (Gordon Institute of Business Science Pretoria 2020)

Memeti and Pllana 2018 Journal of Computational Science

Memeti S and Pllana S "PAPA: A Parallel Programming Assistant Powered by IBM Watson Cognitive Computing Technology" 2018 Journal of Computational Science 275-284

Mongalo 2016 Journal of Corporate and Commercial Law and Practice Mongalo TH "Directors' Standards of Conduct under the South African Companies Act and the Possible Influence of Delaware Law" 2016 Journal of Corporate and Commercial Law and Practice 1-16 
Mneney and Van Belle "Big Data Capabilities"

Mneney J and Van Belle JP "Big Data Capabilities and Readiness of South African Retail Organisations" in IEEE 6th International Conference Cloud System and Big Data Engineering (14-15 January 2016 Noida, India) 279-286

Motau and Kalema "Big Data Analytics Readiness"

Motau M and Kalema BM "Big Data Analytics Readiness: A South African Public Sector Perspective" in IEEE International Conference on Emerging Technologies and Innovative Business Practices for the Transformation of Societies (3-6 August 2016 Balaclava, Mauritius) 1-7

Muniandy and Hillier 2015 Pacific-Basin Finance Journal

Muniandy B and Hillier J "Board Independence, Investment Opportunity Set and Performance of South African Firms" 2015 Pacific-Basin Finance Journal 108-124

Ntim and Osei 2011 AREF

Ntim CG and Osei KA "The Impact of Corporate Board Meetings on Corporate Performance in South Africa" 2011 AREF 83-103

OECD Principles of Corporate Governance

Organisation for Economic Co-operation and Development Principles of Corporate Governance (OECD Paris 2004)

Petrin 2020 Colum Bus L Rev

Petrin M "Corporate Management in the Age of Al" 2020 Colum Bus L Rev 965-1030

Ridge, Johnston and Brian 2015 Afr J Bus Manage

Ridge M, Johnston K and Brian D "The Use of Big Data Analytics in the Retail Industries in South Africa" 2015 Afr J Bus Manage 688-703

Rosenstein and Wyatt 1997 Journal of Financial Economics Rosenstein S and Wyatt JG "Inside Directors, Board Effectiveness, and Shareholder Wealth" 1997 Journal of Financial Economics 229-250

Terjesen, Couto and Francisco 2016 JMG

Terjesen S, Couto EB and Francisco PM "Does the Presence of Independent and Female Directors Impact Firm Performance? A MultiCountry Study of Board Diversity" 2016 JMG 447-483 
United States Senate Role of the Board of Directors in Enron's Collapse Permanent Subcommittee on Investigations of the Committee on Governmental Affairs, United States Senate The Role of the Board of Directors in Enron's Collapse: Report Prepared by the Permanent Subcommittee on Investigations of the Committee on Governmental Affairs: United States Senate (US Government Printing Office Washington 2002)

Valentine and Stewart 2013 IJDG

Valentine ELH and Stewart G "The Emerging Role of the Board of Directors in Enterprise Business Technology Governance" 2013 IJDG 346-362

Van Tonder 2018 Obiter

Van Tonder JL "A Primer on the Directors' Oversight Function as a Standard of Directors' Conduct under the Companies Act 71 of 2008" 2018 Obiter 302-316

Viviers and Mans-Kemp 2019 IJDG

Viviers S and Mans-Kemp N "Director Overboardedness in South Africa: Evaluating the Experience and Busyness Hypotheses" 2019 IJDG 68-81

\section{Case law}

Australian Securities and Investments Commission v Healey (No 2) [2011] FCA 1003

Charitable Corporation v Sutton (1742) 26 ER 642

Hlumisa Investment Holdings (RF) Limited v Kirkinis 20194 SA 569 (GP)

OUTA NPC v Myeni 2019 ZAGPPHC 957 (12 December 2019)

SABC v Mpofu 20094 All SA 169 (GSJ)

\section{Legislation}

Broad-Based Black Economic Empowerment Act 53 of 2003

Companies Act 71 of 2008

Companies Act 992 of 2019 (Ghana)

Companies and Other Business Entities Act 4 of 2019 


\section{Government and other relevant publications}

Code of Best Practices for Corporate Governance (2010) (Ghana)

Code of Corporate Governance Practices for Issuers of Securities to the Public (2015) (Kenya)

Johannesburg Stock Exchange (JSE) Listing Requirements 2020

\section{Internet sources}

Bravard 2015 https://hbr.org/2015/09/all-boards-need-a-technology-expert Bravard J 2015 All Boards Need a Technology Expert https://hbr.org/2015/09/all-boards-need-a-technology-expert accessed 10 September 2020

High 2012 https://developer.ibm.com/watson/wp-content/uploads/sites/19/ 2013/11/The-Era-of-Cognitive-Systems-An-Inside-Look-at-IBM-Watsonand-How-it-Works.pdf

High R 2012 The Era of Cognitive Systems: An Inside Look at IBM Watson and How it Works https://developer.ibm.com/watson/wpcontent/uploads/sites/19/2013/11/The-Era-of-Cognitive-Systems-AnInside-Look-at-IBM-Watson-and-How-it-Works.pdf accessed 5 June 2021

ITWeb Staff Writer 2013 https://www.itweb.co.za/content/nkLgB1 MebBbq59N4

ITWeb Staff Writer 2013 SA Corporates Lag on Big Data Analytics https://www.itweb.co.za/content/nkLgB1MebBbq59N4 accessed 28 October 2020

McCarthy Date unknown http://jmc.stanford.edu/artificial-intelligence/whatis-ai/index.html

McCarthy J Date unknown What is Al? Basic Questions http://jmc.stanford.edu/artificial-intelligence/what-is-ai/index.html accessed 29 September 2020

Microsoft News Center 2020 https://news.microsoft.com/en$\mathrm{xm} / 2020 / 02 / 19 /$ these-are-the-skills-south-africa-needs-to-compete-in-the4th-industrial-revolution/

Microsoft News Center 2020 These are the Skills South Africa Needs to Compete in the 4th Industrial Revolution https://news.microsoft.com/en$\mathrm{xm} / 2020 / 02 / 19 /$ these-are-the-skills-south-africa-needs-to-compete-in-the4th-industrial-revolution/ accessed 28 October 2020 
Provost and Fawcett 2013 https://pubmed.ncbi.nlm.nih.gov/27447038/

Provost F and Fawcett T 2013 Data Science and its Relationship to Big Data and Data-Driven Decision Making https://pubmed.ncbi.nlm.nih.gov/27447038/ accessed 28 October 2020

SYSPRO $2018 \quad$ https://www.researchandmarkets.com/reports/ 4715503/mobile-corporation-in-south-africa-2018

SYSPRO 2018 Mobile Corporation in South Africa 2018 https://www.researchandmarkets.com/reports/4715503/mobilecorporation-in-south-africa-2018 accessed 27 October 2020

\section{List of Abbreviations}

Afr J Bus Manage

AGM

Al

Alb L Rev

AREF

ASIC

CAIS

Cambridge $\mathrm{J}$ Reg Econ Soc

Clin J Oncol Nurs

Colum Bus L Rev

EJISDC

GFC

Harv Int'I LJ

IBM

IEEE

IJDG

IODSA

IT

J Oncol Pract

JBF

JMG

JSE
African Journal of Business Management annual general meeting

artificial intelligence

Albany Law Review

African Review of Economics and Finance

Australian Securities and Investments Commission

Communications of the Association for Information Systems

Cambridge Journal of Regions, Economy and Society

Clinical Journal of Oncology Nursing

Columbia Business Law Review

Electronic Journal of Information Systems in Developing Countries

global financial crisis

Harvard International Law Journal

International Business Machines

Institute of Electrical and Electronics Engineers

International Journal of Disclosure and Governance

Institute of Directors of South Africa

information technology

Journal of Oncology Practice

Journal of Banking and Finance

Journal of Management and Governance

Johannesburg Stock Exchange 
OECD

OUTA

RBT

SA Merc LJ

Stell LR

USA

Vand L Rev

VITAL
Organisation for Economic Co-operation and Development

Organisation Undoing Tax Abuse resource-based theory

South African Mercantile Law Journal

Stellenbosch Law Review

United States of America

Vanderbilt Law Review

Validating Investment Tool for Advancing Life

Sciences 